\title{
A recursive path model for estimation of the live weight using some body measurements in Awassi sheep
}

\author{
Doğukan ÖZEN ${ }^{1 a \varpi}$, Afşin KOCAKAYA ${ }^{2 b}$, Necmettin ÜNAL ${ }^{2 c}$, Ceyhan ÖZBEYAZ $^{2 d}$ \\ ${ }^{1}$ Ankara University, Faculty of Veterinary Medicine, Department of Biostatistics, ${ }^{2}$ Ankara University, Faculty of Veterinary \\ Medicine, Department of Animal Breeding and Husbandry, Ankara, Turkey \\ aORCID: 0000-0003-1943-2690; ' $\mathrm{ORCID:} \mathrm{0000-0003-2023-8895;}{ }^{\mathrm{C}}$ ORCID: 0000-0001-5250-7063; \\ dORCID: 0000-0002-3748-9992
}

${ }^{凶}$ Corresponding author: ozen@ ankara.edu.tr Received date: 15.01 .2019 - Accepted date: 30.04 .2019

\begin{abstract}
Aim of this study was to investigate direct, indirect and total effects of body measurements on live weight in Awassi sheep and to derive prediction equations for estimation of the live weight. Live weight, head length, body length, withers height, chest depth, chest width and rump height measurements of 270 Awassi sheep at the age of 2-4 years raised at a private farm in Eskişehir Province, Turkey was used. A recursive path model was established to estimate the live weight of the Awassi sheep using these body measurements. Results showed that there was a significant indirect effect of withers height, rump height and body length and significant direct effect of chest depth, chest width and head length on live weight. The strongest predictor of live weight was chest depth, followed by chest width and head length. In conclusion, the equations given in this study could serve as a practical tool to predict the live weight of Awassi sheep.
\end{abstract}

Keywords: Awassi sheep, live weight, path analysis, structural equation modelling.

\section{İvesi koyunlarda bazı vücut ölçüleri yardımıyla canlı ağırlığın tahmin edilmesinde kullanılabilecek rekursif bir path modeli}

Özet: Bu çalışmanın amacı, İvesi ırkı koyunlarda çeşitli vücut ölçülerininin canlı ağırlık üzerine doğrudan, dolaylı ve toplam etkilerini incelemek ve bu ölçülerden yararlanarak canlı ağırlığı tahmin edecek bir model oluşturmaktır. Bu amaçla, Eskişehir ilinde özel bir çiftlikte yetiştirilen 2-4 yaşlarındaki toplam 270 İvesi ırkı koyunun canlı ağırlığı, baş uzunluğu, gövde uzunluğu, cidago yüksekliği, göğüs derinliği, gögüs genişliği ve sağrı yüksekliği ölçümleri elde edilmiştir. Bu ölçümler yardımıyla canlı ağırlığı tahmin etmek için rekursif bir path modeli oluşturulmuştur. Elde edilen sonuçlar, cidago yüksekliği, sağrı yüksekliği ve vücut uzunluğunun vücut ağırlığına dolaylı; göğüs genişliği, göğüs derinliği ve baş uzunluğunun ise doğrudan etkisinin olduğunu göstermiştir. Canlı ağırlı̆̆ın en güçlü belirleyicisi göğüs derinliği, ardından göğüs genişliği ve baş uzunluğu olarak belirlenmiştir. Sonuç olarak, bu çalışmada verilen denklemlerin, İvesi koyunlarının canlı ağırlı̆ını tahmin etmek için pratik bir araç olarak kullanılabileceği ortaya konmuştur.

Anahtar sözcükler: Canlı ağırlık, İvesi koyunu, path analizi, yapısal eşitlik modeli.

\section{Introduction}

Awassi is a multipurpose fat-tailed sheep breed with high adaptability and is one of the most widespread breeds in the Middle East and Southwest Asia $(3,25)$. The Awassi breed has been raised in South-eastern Anatolia, Syria, Iraq, Israel. It has also been introduced into many countries like Australia, India, Macedonia, Ethiopia, Spain, and New Zealand to study its performance and to be crossed with native breeds, showing its importance (34). Taking into consideration the place of lamb meat and milk in the food supply, the breed also has an essential role in Turkey, despite the declining numbers.
The body measurements of livestock give useful information about their morphological structure. Determination of live weight and body measurements in certain periods in sheep breeding are essential in terms of monitoring growth of the sheep so that it can be useful to make appropriate management decisions. Also, the estimation of live weight using various body measurements could be practical and relatively easy for breeders with insufficient resources (18).

Many studies showed the close relationship between live weight and various body measurements and also reported on the use of various body measurements of 
animals to determine live body weight of cattle $(1,10,21)$, sheep $(2,9,14,15,24,29)$ goat $(16,18)$ and pig (30). However, most of these authors deal with these linear measurements using correlation coefficients and multiple regression methods. On the other hand, examining only the direct effect of one variable on another may also not be optimal as in multiple regression model since some of the effects of an independent variable on a dependent variable may be transmitted through intervening variables. For that reason, a more suitable method to evaluate the relationship among these variables is needed.

Structural equation modeling (SEM) is a secondgeneration multivariate analysis technique that encompasses a broad array of statistical techniques such as path analysis, confirmatory factor analysis, latent growth models, item response theory and even including multiple linear regression (11). A Path model, which is the application of structural equation modeling without latent variables, could provide greater flexibility to test the structure coefficients on a theoretical basis. Although different models were used, the application of this technique is limited and reported in Karacabey Merino sheep (4), Yankasa sheep (33), Sahiwal cattle (17) and Landrace $\times$ Large White pigs (13).

The aim of this study was (1) to evaluate direct, indirect and total effects of various body measurements on live weight of Awassi sheep breed using structural equation modeling technique and (2) to show this technique's advantages over multiple regression analysis.

\section{Material and Methods}

In this study, a total of 270 Awassi ewes at the age of 2-4 years raised in a private enterprise at Eskişehir Province, Turkey was used (19). Eskişehir has a continental climate with very cold winters, hot summers and relatively sparse precipitations. The data collected after the shearing season and the temperatures range between $19.5^{\circ} \mathrm{C}$ and $33^{\circ} \mathrm{C}$ during the study period. The ewes were produced under semi-intensive management system and fed with the routine programme of the farm. Live weight was taken using a digital scale $(\mathrm{kg})$ sensitive to $50 \mathrm{~g}$. The body measurements taken from animals were as follows:

Head Length: Frontal distance from mouth to poll,
Chest Depth: Vertical distance from the top of the withers to the xiphoid process,

Chest Width: Maximum intercostal diameter at the level of the $6^{\text {th }}$ rib, just behind the articulatio humeri,

Body Length: the distance from the tip of sternum to the base of the tail,

Withers Height: The distance from shoulder blades (the top of the withers) to the ground,

Rump Height: The distance from the top of the rump to the ground.

All body measurements were taken using tailor's tape measure and measuring stick while all animals were in standing position with head raised and weight on all four feet without body movement.

Statistical analysis: Descriptive statistics were calculated and presented as "Mean \pm Standard error of the mean" for all variables. Pearson's correlation analysis was used to determine the strength and direction of the relationships among the variables. A preliminary assessment was performed using the multiple regression analysis with backward elimination method to identify the variables to be included in the path analysis. VIF and tolerance statistics were employed to analyse multicollinearity. In path analysis, the parameter estimates were obtained using the maximum likelihood method whereas observed information matrix (OIM) technique was used to obtain the variance-covariance matrix of the parameter estimates. Modification indices were used to give an empirical basis for making model modifications on theoretical sense to improve model fit. The goodness of fit testing of the model was evaluated by the following indexes: comparative fit index (CFI), Tucker-Lewis index (TLI), the root mean square error of approximation (RMSEA) and standardized root mean square residual (SRMR). STATA 12.1 MP4 statistical package was used for all statistical analysis. A p value less than 0.05 was considered statistically significant.

\section{Results}

Descriptive statistics for all variables in the model were calculated and presented in Table 1. The Pearson's correlation coefficients among live weight and the body measurements were given in detail in Table 2. The strongest correlation was between rump height and withers height $(\mathrm{r}=0.764, \mathrm{P}<0.001)$.

Table 1. Descriptive statistics of the variables that are used in the model $(n=270)$.

Tablo 1. Modelde kullanılan değişkenlere ilişkin tanımlayıcı istatistikler ( $\mathrm{n}=270)$.

\begin{tabular}{|c|c|c|c|c|c|}
\hline Variable & Mean & Standard deviation & Median & Minimum & Maximum \\
\hline Live weight (kg) & 47.2 & 4.8 & 47.4 & 37 & 64.1 \\
\hline Head length $(\mathrm{cm})$ & 19.4 & 2.02 & 19.5 & 15 & 24.5 \\
\hline Chest depth $(\mathrm{cm})$ & 30.2 & 1.91 & 30.5 & 24.5 & 35 \\
\hline Chest width (cm) & 18.9 & 1.67 & 18.7 & 14.5 & 29.5 \\
\hline Body length (cm) & 65.2 & 3.31 & 65.5 & 52.5 & 73 \\
\hline Withers height $(\mathrm{cm})$ & 61.4 & 2.46 & 61 & 51 & 67 \\
\hline Rump height (cm) & 58.2 & 2.59 & 59 & 48 & 67 \\
\hline
\end{tabular}


The preliminary multiple regression analysis completed after five steps. After the elimination of nonsignificant variables in each step, the final model included only head length, chest depth and chest width as the significant predictors of live weight. The $\mathrm{R}$ squared value of the final regression model was 0.270 (Table 3).

Using the information from the preliminary multiple regression, a structural equation model was established (Figure 1). The model included three exogenous variables: withers height, rump height, and body length. The only endogenous outcome variable in Figure 1 was live weight, the final outcome. The remaining variables, chest depth, chest width, and head length, were included as endogenous variables that mediate some part of the effect of antecedent variables on subsequent variables. Each of these endogenous variables was explained by other variables in the model (Table 4). R squared for equation level goodness of fit was 0.609 . Relationship between exogenous variables was shown with a curved line. In concordance with the results of the modification indices, the model also considered any possible correlated residuals, assuming that some of the unexplained variances in chest width would be correlated with some of the unexplained variance in head length.

Table 4 shows the path coefficients of the four models for each endogenous variable. Considering the only direct relationship between endogenous mediator variables (chest depth, chest width, head length) and the endogenous outcome variable (live weight), the results were in agreement with preliminary regression model showing that the strongest predictor of live weight was chest depth, followed by chest width and head length (Table 4).

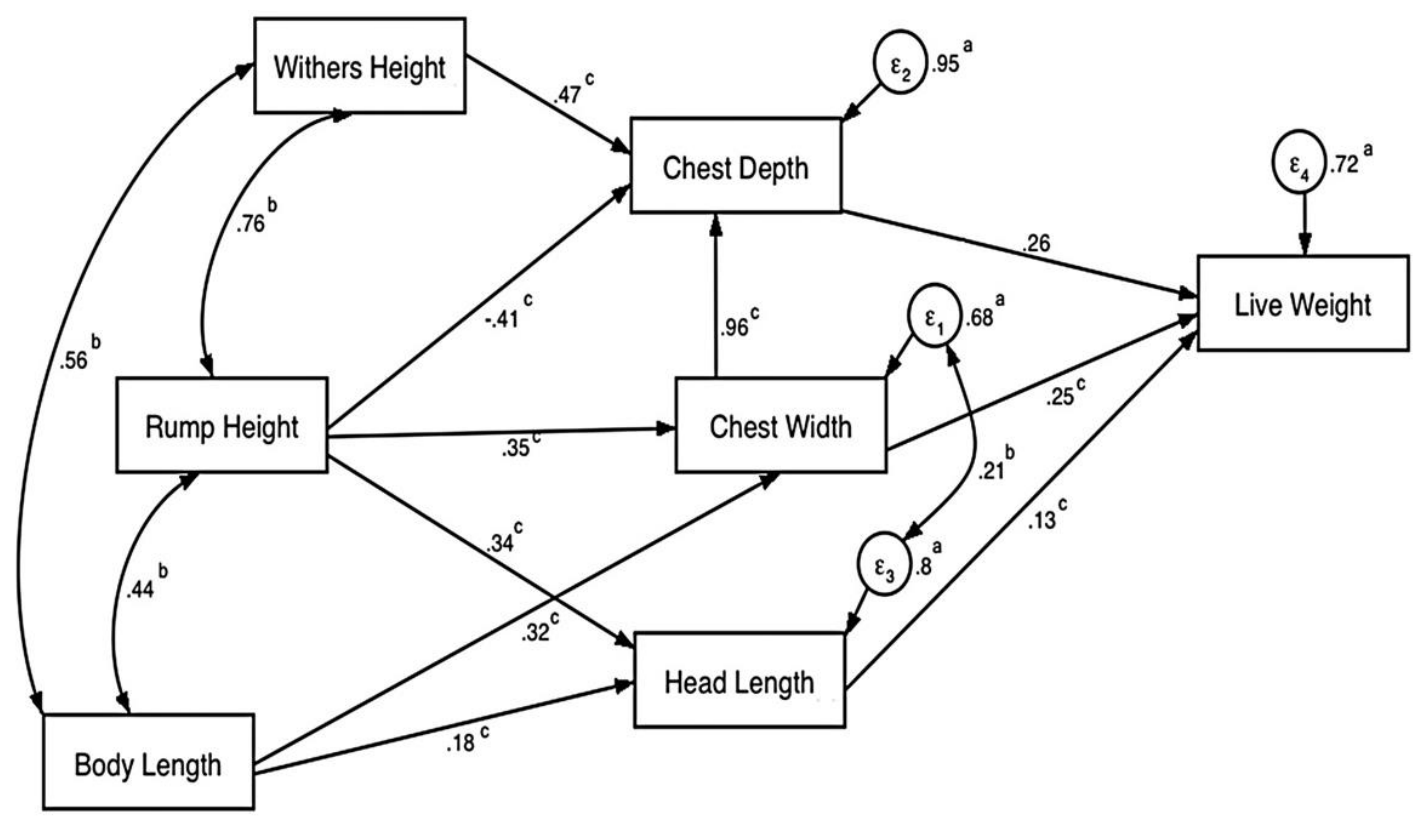

Figure 1. The recursive path model for estimating live weight of Awassi breed. In the figure, estimated variances were represented with the superscript letter a; standardized covariances with b and standardized path coefficients with c.

Şekil 1. İvesi koyunlarında canlı ağırlığın tahmini için oluşturulan rekursif path modeline ilişkin diyagram. Şekilde hesaplanan varyanslar a, standardize edilmiş kovaryanslar b, standardize path katsayıları ise c ile gösterilmiştir.

Table 2. Pearson's correlation coefficients among body measurements and live weight $(n=270)$.

Tablo 2. Vücut ölçüleri ile vücut ağırlığı arasında hesaplanan Pearson korelasyon katsayıları (n=270).

\begin{tabular}{lccccccc} 
& Live weight & Head length & Chest depth & Chest width & Body length & Withers height & Rump height \\
\hline Live weight & 1 & $0.347^{* * *}$ & $0.568^{* * *}$ & $0.542^{* * *}$ & $0.312^{* * *}$ & $0.390^{* * *}$ & $0.322^{* * *}$ \\
Head length & & 1 & $0.503 * * *$ & $0.340^{* * *}$ & $0.327^{* * *}$ & $0.381^{* * *}$ & $0.417 * * *$ \\
Chest depth & & & 1 & $0.553^{* * *}$ & $0.603 * * *$ & $0.668^{* * *}$ & $0.504^{* * *}$ \\
Chest width & & & 1 & $0.518^{* * *}$ & $0.443^{* * *}$ & $0.486^{* * *}$ \\
Body length & & & & & $0.560^{* * *}$ & $0.437^{* * *}$ \\
Withers height & & & & & 1 & $0.764 * * *$ \\
Rump height & & & & & & 1 \\
\hline
\end{tabular}


Table 3. Results of the preliminary multiple regression analysis using live weight as dependent variable and the body measurements as independent variables. Analysis completed after five steps.

Tablo 3. Vücut ağırlı̆̆ı bağımlı değişken, vücut ölçüleri bağımsız değişkenler olmak üzere, ön eleme çoklu regresyon modeli sonucu. Analiz toplam beş adımda gerçekleştirilmiştir.

\begin{tabular}{|c|c|c|c|c|c|c|c|c|c|c|}
\hline \multirow{2}{*}{ क्षे } & \multirow{2}{*}{ Variable } & \multirow{2}{*}{ B } & \multirow{2}{*}{ SE } & \multirow{2}{*}{ Std. B } & \multirow{2}{*}{$\mathbf{t}$} & \multirow{2}{*}{$\mathbf{P}$} & \multicolumn{2}{|c|}{$95 \% \mathrm{CI}$} & \multicolumn{2}{|c|}{ Collinearity statistics } \\
\hline & & & & & & & LB & UB & Tolerance & VIF \\
\hline \multirow{7}{*}{$\overrightarrow{\overrightarrow{0}}$} & (Constant) & 1.982 & 6.94 & & 0.28 & 0.775 & -11.68 & 15.65 & & \\
\hline & Head length & 0.343 & 0.15 & 0.14 & 2.29 & 0.023 & 0.048 & 0.64 & 0.69 & 1.43 \\
\hline & Chest depth & 0.559 & 0.21 & 0.22 & 2.61 & 0.009 & 0.138 & 0.98 & 0.39 & 2.59 \\
\hline & Chest width & 0.797 & 0.19 & 0.28 & 4.13 & $<0.001$ & 0.417 & 1.18 & 0.58 & 1.70 \\
\hline & Body length & -0.056 & 0.11 & -0.04 & -0.52 & 0.603 & -0.27 & 0.16 & 0.49 & 2.06 \\
\hline & Withers height & 0.323 & 0.19 & 0.16 & 1.72 & 0.087 & -0.05 & 0.69 & 0.28 & 3.47 \\
\hline & Rump height & -0.131 & 0.16 & -0.07 & -0.82 & 0.413 & -0.44 & 0.18 & 0.36 & 2.75 \\
\hline \multirow{4}{*}{ 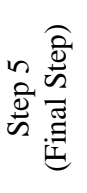 } & (Constant) & 7.194 & 4.12 & & 1.75 & 0.082 & -0.92 & 15.3 & & \\
\hline & Head length & 0.313 & 0.15 & 0.13 & 2.16 & 0.032 & 0.03 & 0.59 & 0.74 & 1.34 \\
\hline & Chest depth & 0.682 & 0.17 & 0.26 & 3.92 & $<0.001$ & 0.34 & 1.03 & 0.58 & 1.71 \\
\hline & Chest width & 0.733 & 0.18 & 0.25 & 4.11 & $<0.001$ & 0.38 & 1.08 & 0.69 & 1.45 \\
\hline
\end{tabular}

B: Beta; SE: Standard error; Std. B: Standardized beta; LB: Lower bound; UB: Upper bound

Table 4. Unstandardized and standardized estimates for the recursive path model.

Tablo 4. Rekürsif path modeline ilişkin standardize edilmiş ve standardize edilmemiş tahminler.

\begin{tabular}{|c|c|c|c|c|c|c|}
\hline \multirow{3}{*}{$\begin{array}{c}\text { Dependent } \\
\text { (Endogenous) } \\
\text { variables }\end{array}$} & \multirow{3}{*}{$\begin{array}{c}\text { Independent } \\
\text { variables }\end{array}$} & \multicolumn{3}{|c|}{ Path coefficients } & \multirow{3}{*}{$\mathbf{z}$} & \multirow{3}{*}{$\mathbf{P}$} \\
\hline & & \multicolumn{2}{|c|}{ Unstandardized } & \multirow{2}{*}{$\begin{array}{c}\text { Standardized } \\
\text { Beta }\end{array}$} & & \\
\hline & & Beta & SE & & & \\
\hline \multirow[t]{3}{*}{ Chest width } & Rump height & 0.224 & 0.035 & 0.346 & 6.29 & $<0.001$ \\
\hline & Body length & 0.163 & 0.027 & 0.321 & 5.85 & $<0.001$ \\
\hline & Constant & -5.085 & 2.09 & & -2.43 & 0.015 \\
\hline \multirow[t]{4}{*}{ Chest depth } & Withers height & 0.358 & 0.047 & 0.472 & 7.57 & $<0.001$ \\
\hline & Rump height & -0.296 & 0.077 & -0.411 & -3.8 & $<0.001$ \\
\hline & Chest width & 1.271 & 0.197 & 0.961 & 6.29 & $<0.001$ \\
\hline & Constant & 2.05 & 2.61 & & 0.79 & 0.432 \\
\hline \multirow[t]{3}{*}{ Head length } & Rump height & 0.26 & 0.046 & 0.339 & 5.69 & $<0.001$ \\
\hline & Body length & 0.108 & 0.036 & 0.179 & 3.01 & 0.003 \\
\hline & Constant & -2.62 & 2.68 & & -1 & 0.318 \\
\hline \multirow[t]{4}{*}{ Live weight } & Chest depth & 0.682 & 0.172 & 0.262 & 4.07 & $<0.001$ \\
\hline & Chest width & 0.733 & 0.177 & 0.253 & 4.056 & $<0.001$ \\
\hline & Head length & 0.313 & 0.144 & 0.128 & 2.183 & 0.029 \\
\hline & Constant & 7.19 & 4.089 & & 1.76 & 0.079 \\
\hline
\end{tabular}

SE: Standard error

Although preliminary regression model showed no significant effect of withers height, rump height and body length on live weight, the path model revealed that there was a significant indirect effect of these three variables (withers height, rump height and body length) on live weight (Table 5). Considering both direct and indirect effects of the variables, the strongest total effect was from chest width followed by chest depth and head length.
The chi-square test of absolute model fit was reported as 12.83, along with 7 degrees of freedom returning with a probability value of $\mathrm{P}=0.076$, which suggests that the model fits the data acceptable. Corroborating evidence is provided by other relative model fit statistics such as RMSEA, CFI, TLI and SRMR suggesting a close approximate model fit to data (Table $6)$. 
Table 5. Direct, indirect and total effects of exogenous variables with their unstandardized beta coefficients.

Tablo 5. Ekzojen değişkenlere ilişkin standardize edilmemiş beta katsayıları ve doğrudan, dolaylı ve toplam etkiler.

\begin{tabular}{|c|c|c|c|c|c|c|c|}
\hline \multirow{2}{*}{$\begin{array}{l}\text { Endogenous } \\
\text { variables }\end{array}$} & \multirow{2}{*}{$\begin{array}{c}\text { Exogenous } \\
\text { variables }\end{array}$} & \multicolumn{2}{|c|}{ Direct effect } & \multicolumn{2}{|c|}{ Indirect effect } & \multicolumn{2}{|c|}{ Total effect } \\
\hline & & Beta & SE & Beta & SE & Beta & SE \\
\hline \multirow[t]{4}{*}{ Chest depth } & Chest width & $1.27 * * *$ & 0.202 & no path & & $1.27 * * *$ & 0.202 \\
\hline & Withers height & $0.358 * * *$ & 0.047 & no path & & $0.358 * * *$ & 0.047 \\
\hline & Rump height & $-0.295 * * *$ & 0.078 & $0.284 * * *$ & 0.073 & -0.011 NS & 0.044 \\
\hline & Body length & no path & & $0.208 * * *$ & 0.026 & $0.207 * * *$ & 0.026 \\
\hline \multirow[t]{2}{*}{ Chest width } & Rump height & $0.224 * * *$ & 0.036 & no path & & $0.224 * * *$ & 0.036 \\
\hline & Body length & $0.163^{* * *}$ & 0.028 & no path & & $0.163 * * *$ & 0.028 \\
\hline \multirow[t]{2}{*}{ Head length } & Rump height & $0.259 * * *$ & 0.046 & no path & & $0.259 * * *$ & 0.047 \\
\hline & Body length & $0.108^{* *}$ & 0.036 & no path & & $0.108^{* *}$ & 0.035 \\
\hline \multirow[t]{6}{*}{ Live weight } & Chest depth & $0.682 * * *$ & 0.173 & no path & & $0.681 * * *$ & 0.172 \\
\hline & Chest width & $0.733 * * *$ & 0.177 & $0.866 * * *$ & 0.138 & $1.599 * * *$ & 0.224 \\
\hline & Head length & $0.313 *$ & 0.144 & no path & & $0.313^{*}$ & 0.144 \\
\hline & Withers height & no path & & $0.244 * * *$ & 0.069 & $0.244 * * *$ & 0.069 \\
\hline & Rump height & no path & & $0.238^{* *}$ & 0.073 & $0.238 * *$ & 0.073 \\
\hline & Body length & no path & & $0.295 * * *$ & 0.048 & $0.295 * * *$ & 0.047 \\
\hline
\end{tabular}

$* \mathrm{P}<0.05$; ** $\mathrm{P}<0.01$; *** $\mathrm{P}<0.001$; NS: $\mathrm{P}>0.05$; SE: Standard error

Table 6. The goodness of fit values of the specified model.

Tablo 6. Oluşturulan modele ilişkin uyum iyiliği kriterleri

\begin{tabular}{lccc}
$\begin{array}{c}\text { Goodness of fit } \\
\text { criteria }\end{array}$ & Close approximate fit & Reasonable approximate fit & $\begin{array}{c}\text { Achieved Goodness of Fit Values for } \\
\text { the Model }\end{array}$ \\
\hline$\chi 2$ & $0 \leq \chi 2 \leq 2 \mathrm{df}$ & $2 \mathrm{sd} \leq \chi 2 \leq 3 \mathrm{df}$ & 11.591 \\
$\mathrm{P}$ value & $0.05<\mathrm{P} \leq 1.00$ & $0.01 \leq \mathrm{P} \leq 0.05$ & 0.072 \\
RMSEA & $0 \leq \mathrm{RMSEA} \leq 0.05$ & $0.05 \leq \mathrm{RMSEA} \leq 0.08$ & 0.057 (PCLOSE $=0.340)$ \\
$\mathrm{CFI}$ & $0.97 \leq \mathrm{CFI} \leq 1.00$ & $0.95 \leq \mathrm{CFI} \leq 0.97$ & 0.994 \\
$\mathrm{TLI}$ & $0.95 \leq \mathrm{TLI} \leq 1.00$ & $0.90 \leq \mathrm{TLI} \leq 0.95$ & 0.978 \\
SRMR & $0 \leq \mathrm{SRMR} \leq 0.04$ & $0.5 \leq \mathrm{SRMR} \leq 0.10$ & 0.02 \\
\hline
\end{tabular}

RMSEA: Root mean square error of approximation; TLI: Tucker-Lewis index; CFI: Comparative fit index; SRMR: Standardized root mean residual

\section{Discussion and Conclusion}

The relationship between live weight and various body measurements is well known in farm animals and it is one of the most important traits for the study of growth pattern and daily management. The accuracy of models used to predict the live weight of farm animals using various body measurements is of immense financial contribution to the enterprise (2).

The present study has shown a statistically significant correlation between live body weight and the body measurements supporting the hypothesis that the body weight could be predicted based on these measurements. The correlation of chest depth and chest width with live body weight were the strongest among other measurements. Previous studies also reported a high correlation between various body measurements and live weight in sheep and goats $(4,5,12,16,20)$.

The most common predictive model used to interpret the relationship between live weight and body measurements are the multiple regression model $(8,23)$. A multiple regression represents a particular model of relationships in which all possible predictors are treated as co-equal and their interrelations are un-analyzed. So that the ability to obtain interpretable results from such models depends on a degree to which their structure matches the true relations among variables. Choosing a secondgeneration multivariate technique, however, could increase chances of discovering the relationship between dependent variables as well as between independent variables and dependent variables from one-time analysis simultaneously. Also, it is possible to show the direct effect, indirect effect and total effect via mediation. In this study, we have specified a mediational model where the effect of height at withers, rump, body length and head length on live weight flow through chest width and chest depth so chest width and chest depth are mediating variables between exogenous variables and the live weight. Although the provided model fits the data very well and ensures a theoretically consistent set of evidence, it is also possible that there may be other equivalent or non-equivalent models that fit the data well or even better. 
One of the interesting and important findings of this study was a non-significant effect of withers height, rump height and body length in the preliminary multiple regression model. Topal et al. (28) also established a multiple regression model for Awasi breed in which there is no significant effect of these three variables in a similar manner. However, many previous studies with different breeds showed a significant direct effect of these three variables and these variables were included in their models $(5,15,27)$. Using the advantage of structural equation modeling technique, it was revealed that these variables had no significant direct but indirect effects on live weight. This finding was also a good example to show the importance of the correct selection of techniques to reveal the relationship between variables. The final model revealed that the highest total effect to the live weight was chest width and chest depth which is inconsistent with the previous studies $(4,15,28,33)$.

It has been well known that there is a high phenotypic correlation between live weight and heart girth $(2,24)$. However, heart girth measurement was not included in the analysis, which could be considered as a limitation of the study. One of the issues with the current data was the high correlation of heart girth with live weight, chest depth and withers height measurements resulting in multicollinearity, which causes estimates of standardized partial regression coefficients and path coefficients to be less precise, less accurate and prone to rounding error (22). Collinearity implies that the effect of one predictor cannot be uniquely identified with the effect of another predictor. In such circumstances, the statistical model can include only one of the two predictors. Many alternative models such as PCA regression, PLS regression, Ridge regression, Lasso regression, etc have been proposed in the literature to address multicollinearity problem (7), however, this issue is out of the scope of this study. In this study, heart girth was excluded from the analysis among the collinear variables according to Weisberg's criteria (31). In this context, previous studies also reported collinearity between heart girth and withers height, despite the fact that different methodology was used to dealing with this problem $(6,26,32)$.

According to the results of this study, it could be concluded that live weight can be predicted on the basis of linear body measurements in Awassi sheep breed. The established path model improved model fit compared to the multiple regression model and provided a great advantage by evaluating the indirect effects of some body measurements.

\section{References}

1. Abdelhadi O, Babiker S (2009): Prediction of zebu cattle live weight using live animal measurements. Livest Res Rural Dev, 21, 1-7.
2. Afolayan R, Adeyinka I, Lakpini C (2006): The estimation of live weight from body measurements in Yankasa sheep. Czech JAnim Sci, 51, 343.

3. Akçapınar H (2000): Koyun Yetiştiriciliği: ismat matbaası.

4. Ambacioğlu P, Kaya U, Ozen D, et al. (2017): $A n$ Examination of the Relationships Between Live Weight and Body Measurements in Karacabey Merino Sheep Through the Path Analysis Approach. Kafkas Univ Vet Fak Derg, 23, 857-863.

5. Atta M (2004): Use of heart girth, wither height and scapuloischial length for prediction of liveweight of Nilotic sheep. Small Rumin Res, 55, 233-237.

6. Aziz M, Sharaby M (1993): Collinearity as a problem in predicting body weight from body dimensions of Najdi sheep in Saudi Arabia. Small Rumin Res, 12, 117-124.

7. Dormann CF, Elith J, Bacher S, et al. (2013): Collinearity: a review of methods to deal with it and a simulation study evaluating their performance. Ecography, 36, 27-46.

8. Draper NR, Smith H (2014): Applied regression analysis: John Wiley \& Sons.

9. Fajemilehin OS, Salako A (2008): Body measurement characteristics of the West African Dwarf (WAD) Goat in deciduous forest zone of Southwestern Nigeria. Afr J Biotechnol, 7, 2521-2526.

10. Goe M, Alldredge J, Light D (2001): Use of heart girth to predict body weight of working oxen in the Ethiopian highlands. Livest Prod Sci, 69, 187-195.

11. Jeon J (2015): The strengths and limitations of the statistical modeling of complex social phenomenon: Focusing on SEM, path analysis, or multiple regression models. Int J Soc Behav Educ Econ Bus Ind Eng, 9, 15591567.

12. Koyuncu M, Tuncel E (1992): The relationships between hair characteristics, live weight and body measurements in Anatolian Black Goats. Uludag Univ Sci Inst Pub, 20.

13. Machebe N, Ezekwe A, Okeke G, et al. (2016): Path analysis of body weight in grower and finisher pigs. Indian J Anim Res, 50, 794-798.

14. Mahieu M, Navès M, Arquet R (2011): Predicting the body mass of goats from body measurements. Livest Res Rural Dev, 23.

15. Mahmud MA, Shaba P, Abdulsalam W, et al. (2014): Live body weight estimation using cannon bone length and other body linear measurements in Nigerian breeds of sheep. J Adv Vet Anim Res, 1, 169-176.

16. Mohammed I, Amin J (1997): Estimating body weight from morphometric measurements of Sahel (Borno White) goats. Small Ruminant Research, 24, 1-5.

17. Naskar S, Banik S, Tomar S (2006): Contribution of different characters to lactation milk yield of Sahiwal cattleA path analysis approach. Indian J Anim Sci, 76, 618.

18. Nsoso S, Aganga A, Moganetsi B, et al. (2003): Body weight, body condition score and heart girth in indigenous Tswana goats during the dry and wet seasons in southeast Botswana. Livest Res Rural Dev, 15, 1-7.

19. Özbeyaz C, Bilgiç ÖF, Kocakaya A, et al. (2018): Investigation of some traits of Awassi sheep in breeder conditions in Eskişehir. Lalahan Hay Arast Enst Derg, 58, $1-6$. 
20. Ozturk A, Kayis S, Parlat S, et al. (1994): The possibilities of estimating the live weight using some body measurements in Konya Merino. J Anim Res, 4, 23-26.

21. Paul SS, Das KS (2012): Prediction of Body Weight from Linear Body Measurements in Nili-Ravi Buffalo Calves. J Buffalo Sci, 1, 32-34.

22. Petraitis P, Dunham A, Niewiarowski P (1996): Inferring multiple causality: the limitations of path analysis. Functional ecology, 10, 421-431.

23. Sangun L, Cankaya S, Kayaalp GT, et al. (2009): Use of factor analysis scores in multiple regression model for estimation of body weight from some body measurements in Lizardfish. J Anim Vet Adv, 8, 47-50.

24. Sowande O, Sobola O (2008): Body measurements of West African dwarf sheep as parameters for estimation of live weight. Tropic Anim Health Prod, 40, 433-439.

25. Talafha AQ, Ababneh MM (2011): Awassi sheep reproduction and milk production. Tropic Anim Health Prod, 43, 1319-1326.

26. Tariq MM, Eyduran E, Bajwa MA, et al. (2012): Prediction of Body Weight from Testicular and Morphological Characteristics in Indigenous Mengali Sheep of Pakistan using Factor Analysis Scores in Multiple Linear Regression Analysis. Int J Agric Biol, 14, 590-594.

27. Thobela Louis T, Yolisa Florance T, Akhona Lucy T, et al. (2015): A Study of Relationship between Body Weight and Morphological Traits by using Path Analysis in South African indigenous Sheep. J Biol Agri Health, 5, 1-5.
28. Topal M, Yildiz N, Esenbuğa N, et al. (2003): Determination of best fitted regression model for estimation of body weight in Awassi sheep. J Appl Anim Res, 23, 201208.

29. Valdez C, Tupas D, Matias J (1997): Determination of body weight in sheep using external body measurements. Philipp J Vet Med, 34, 25-31.

30. Walugembe M, Nadiope G, Stock J, et al. (2014): Prediction of live body weight using various body measurements in Ugandan village pigs. Livest Res Rural Dev, 26, 1.

31. Weisberg S (2005): Applied linear regression, John Wiley $\&$ Sons. New York, USA.

32. Yakubu A (2011): Fixing multicollinearity instability in the prediction of body weight from morphometric traits of White Fulani cows. J Centr EuroAgri, 11, 487-492.

33. Yakubu A (2010): Path coefficient and path analysis of body weight and biometric traits in Yankasa lambs. Slovak J Anim Sci, 43, 17-25.

34. Zarkawi M (1997): Monitoring the reproductive performance in Awassi ewes using progesterone radioimmunoassay. Small Ruminant Res, 26, 291-294. 